\title{
Sesquicentennial of the birth of Edmund Faustinus Biernacki, a discoverer of the erythrocyte sedimentation rate
}

\author{
Eugeniusz J. Kucharz \\ Department of Internal Medicine and Rheumatology, Medical University of Silesia, Katowice, Poland
}

\begin{abstract}
Edmund Faustinus Biernacki (1866-1911) was a Polish physician and philosopher of medicine. He described erythrocyte sedimentation, designed equipment to measure the erythrocyte sedimentation rate, and applied it to clinical practice. His contribution to the development of one of the most commonly used medical laboratory tests is forgotten, and the test is attributed to other scientists.
\end{abstract}

Key words: Biernacki, Edmund Faustinus, erythrocyte sedimentation rate, history of medicine, biography.

This short paper pays tribute to Edmund Faustinus Biernacki, a great Polish physician on the occasion of the sesquicentennial of his birth. Despite his relatively short life (Biernacki died at age 45), he left a significant legacy to medicine (Fig. 1). His most important discovery, the application of measurement of the rate of erythrocyte sedimentation, is often forgotten and attributed to other scientists (Fåhræus, Westergren) or to those who had described earlier the phenomenon but had not introduced it into clinical practice.

The erythrocyte sedimentation rate (ESR) was probably the most widely applied laboratory test in medical practice. As time went on, the ESR was substituted by other so-called acute phase reactants, and sometimes was considered an old-fashioned or outdated medical laboratory procedure. On the other hand, rheumatologists still apply the ESR, e.g. in calculation of indices of rheumatoid arthritis activity. Summing up, ESR is an important test and its introduction to clinical medicine more than a century ago was a significant stride forward in medicine [1].

Application of bloodletting as a therapeutic measure was probably the first source of observation of the difference in clotting of blood obtained from patients with fever. Their blood formed a clot known as "crusta phlogistica" [2, 3]. Later the phenomenon was described by various physicians, including Richard Davies (in 1760), William Hewson (in 1772), John Hunter (in 1774), and Christian Friedrich Nasse and Hermann Nasse in 1836.

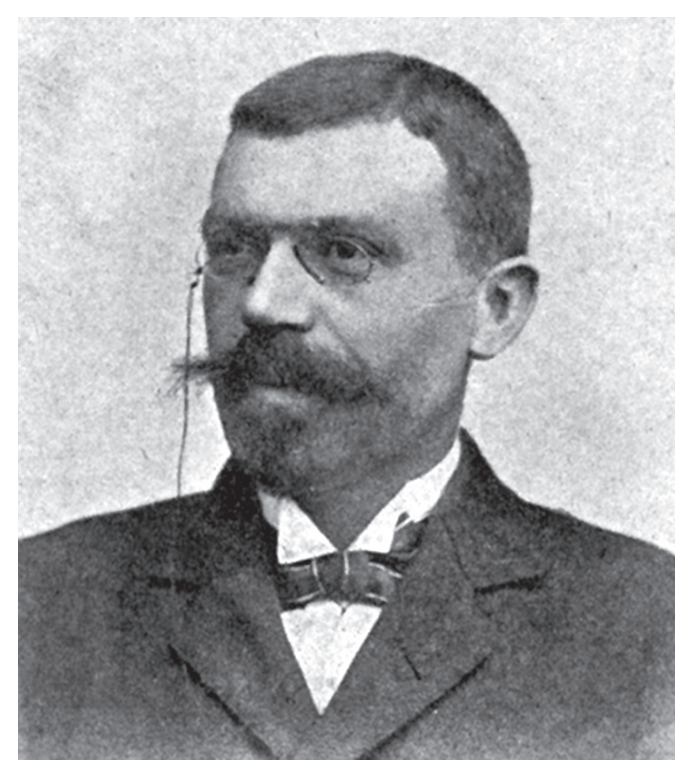

Fig. 1. Edmund Faustinus Biernacki (photo about 1905).

All of them just tested the speed of erythrocyte sedimentation, and some of them noticed a difference in the rate in various blood samples [4].

Edmund F. Biernacki was the first scientist to design a special glass tube or cylinder to measure the ESR, and reported different rates of sedimentation in patients with several disorders, including rheumatic fever (Fig. 2). He

Address for correspondence:

Eugeniusz J. Kucharz, Department of Internal Medicine and Rheumatology, Medical University of Silesia, Ziołowa 45/47, 40-635 Katowice,

Poland, e-mail: ejkucharz@poczta.onet.pl

Submitted: 15.12.2016; Accepted: 15.02.2017 


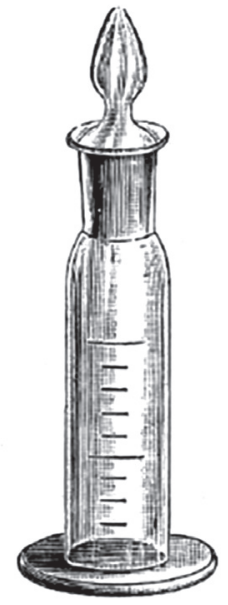

\section{Halbschematische \\ Abbildung des Sedi- \\ mentirungsgefässes.
Natürliche Grösse.}

Fig. 2. A cylinder designed by Biernacki for measurement of the ESR (from Deutsche Medizinische Wochenschrift 1897).

published his papers on the ESR in 1894 and 1897 in Polish and German [5-10] (Fig. 3-5). German in those days served as an international language of medicine, and it is surprising that Biernacki's discoveries were not recognized by the medical world. In 1918, Robert Robin Sanno Fåhræus (1888-1968) tried to apply the ESR as a pregnancy test [11]. Later, in 1921, he reported increased ESR in patients suffering from various inflammatory states [12]. In the same year, Alf Vilhem Albertsson Westergren (1891-1968) described higher ESR in patients with tuberculosis $[13,14]$. He substituted sodium oxalate with sodi-
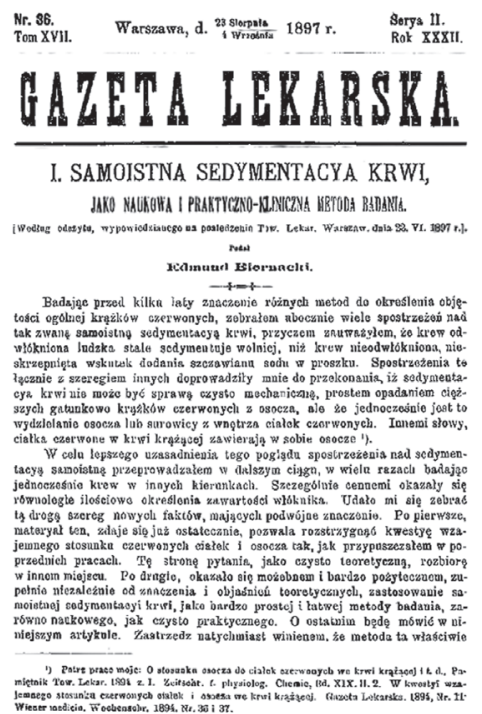

Fig. 4. Biernacki's paper on the ESR from 1897 in Polish [6].

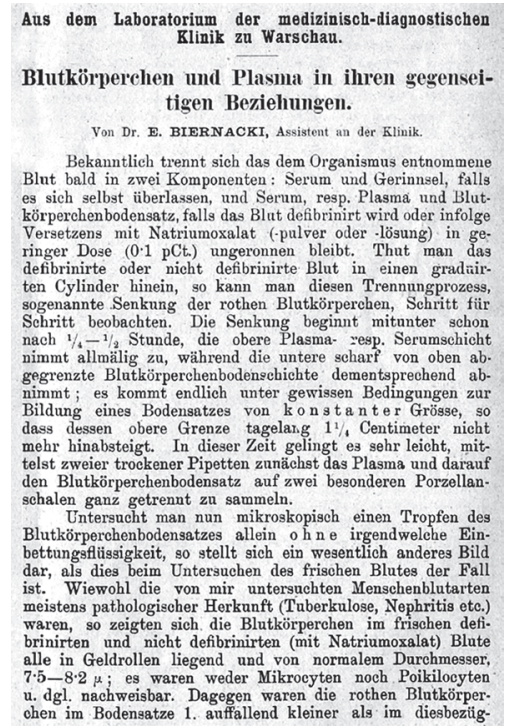

Fig. 3. Biernacki's paper on the ESR from 1894 in German [8].

um citrate as an anticoagulant agent used for ESR measurement, and the currently applied method is known as the Westergren method. During the First World War, the Polish immunologist Ludwik Hirszfeld (1884-1954) published his observations on the ESR in patients with malaria, but his observations were unnoticed [15].

The Polish Society of Internal Medicine in 1923 adopted the term "the Biernacki's reaction" (odczyn Biernackiego) for the ESR, and this term is used regularly in Poland [16]. Unfortunately, the discovery of Biernacki remains almost unknown in the world medical litera-

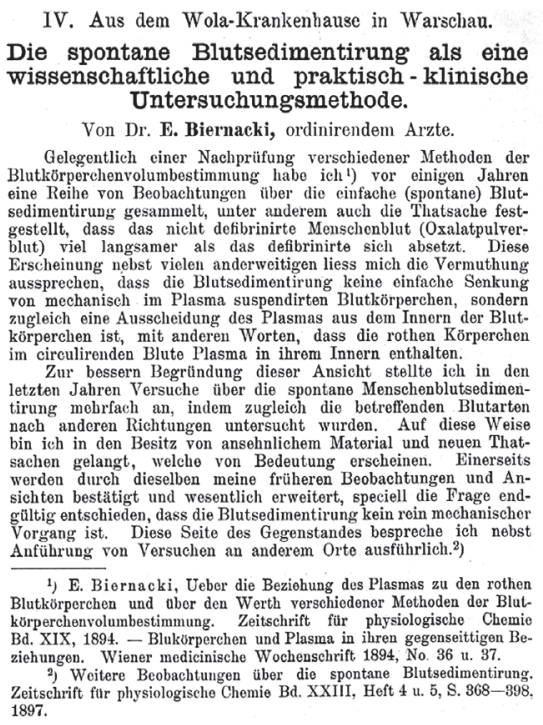

Fig. 5. Biernacki's paper on the ESR in German from 1897 [10]. 
ture. One of the first papers on this subject published in a language other than Polish appeared in print in 1975 and later in 1987 [3, 17-20]. They were followed by other English-language publications. In 2011, Grzybowski [21] submitted a letter to the editor of the Journal of Rheumatology concerning the priority of Biernacki, and the role of Biernacki in the discovery of the ESR was confirmed by Matteson et al. [22], who had earlier attributed it to Fåhræus [23]. Despite the effort of the few Polish physicians interested in the history of medicine [24-26], it is not uncommon to find a currently published paper on application of the ESR in rheumatology (or other fields of medicine) containing wrong data on the discovery of the ESR (for example, Olshaker and Jerrard in 1997 [27] attributed the discovery of the ESR to the 'German' (sic) scholar Fåhræus). Erroneous data concerning the ESR also appear in several handbooks (see: Dąbrowski and Skotnicki [2]). The 150 th anniversary of the birth of Edmund Faustinus Biernacki is another opportunity to highlight the life and achievements of the great physician.

Edmund F. Biernacki was born on the $19^{\text {th }}$ of December, 1866, in the city of Opoczno in the central part of Poland (Łódź Province). In the $19^{\text {th }}$ century, Poland was partitioned by Russia, Germany and Austria, and Opoczno was located in the part occupied by the Russian Empire. His father, Adolf Biernacki, was an office worker and was a descendent of a Polish noble family with a coat of arms, "Poraj". The family originated from the lands of Lithuania, and their estates were confiscated by the Russian authorities as a punishment for the family support for the Polish Independence Insurrection (called the January Insurrection). Adolf Biernacki was persecuted and forced to move from the land estate to the city. The mother of Edmund was Joanna Josephine from the noble family of Baranowski [28-30].

Edmund F. Biernacki attended high schools in Kielce and Lublin and completed his high school education in 1884. In the same year, he enrolled in the Faculty of Medicine of the Imperial University of Warsaw with Russian as the language of instruction [3]. Edmund F. Biernacki was a talented student. He was interested in physiology and carried out research. While still a medical student, he published his first papers [31, 32]. The student achievements of Biernacki were appreciated, and he was awarded the university gold medal for outstanding students (1888). After graduating in 1889 cum eximia laude Biernacki became an assistant of Professor Mikhail Zieniec, the head of the Department of Internal Medicine at the Imperial University of Warsaw [33, 34]. A year later, he received a scholarship and went abroad. He worked in Heidelberg (Professors Wilhelm Heinrich Erb and Wilhelm Kühn), Paris (Professors Jean-Martin Charcot and
George Hayem) and Giessen (Franz Riegel) [35-37]. On his return, Biernacki obtained the post of head of a ward at the Department of Diagnostics in Internal Medicine at the Imperial University of Warsaw under Professor Mikhail Zieniec. Later, in 1897, he obtained the post of chief executive officer of the Municipal Hospital in Wola, a quarter of Warsaw. The Russian authorities hindered development of the hospital, and in 1902, Edmund F. Biernacki decided to move to Lvov. Lvov was a Polish city located in part of Poland partitioned by Austria. Poles had greater rights there than in other parts of Poland occupied by Russia or Germany [30].

Edmund F. Biernacki was a famous physician and scientist, and the Faculty of Medicine at Lvov University decided to waiver him from the formal recognition procedure of the Russian diploma. He was also granted the post of associate professor. He became an Austrian citizen and worked at the university. From 1908, during the summer, Biernacki ran a medical practice in one of the most famous health resorts of Europe, in Karlsbad [38]. Edmund F. Biernacki died suddenly, probably due to rupture of a cardiac aneurysm, on the $29^{\text {th }}$ of December 1911 in Lvov. He left his wife, Caroline Catherine née Rudowska from the Rumoka estate, near Warsaw. He married her in 1892. The Biernackis had one daughter, Ann (born 1892 in Warsaw), married name Bryłowa. Ann had no children [28, 29, 37].

Edmund F. Biernacki had two brothers, Victor Biernacki and Joseph Biernacki. Victor Biernacki (1869-1918) was a famous physicist and one of the first Poles to investigate radio waves. He was also a pioneer in the medical application of X-rays. Victor Biernacki demonstrated his first radiographs at the meeting of the Warsaw Medical Society on the $18^{\text {th }}$ of February, 1896, while Wilhelm Conrad Röntgen discovered $X$-rays on the $8^{\text {th }}$ of November, 1895. The second brother, Joseph, was an engineer and worked in the city of Kamienskoy (now: Dniepropietrovsk, Ukraine).

Edmund F. Biernacki was a very prolific scientist, and he authored almost one hundred research papers. Most of his studies were focused on hematology, but he also was interested in gastrology and general internal medicine. Biernacki was the author of the first Polish handbook of hematology ("Zarys patologii krwi") (1908) ("An outline of blood pathology") [39]. He described a new symptom, paralysis of the ulnar nerve in patients with long-lasting syphilis. The symptom is known as the Biernacki sign [40-44].

Another important field of interest of Edmund F. Biernacki is philosophy of medicine. He published a book on epistemology in medicine, "Istota i granice wiedzy lekarskiej" (1899) ("The nature and limits of medical knowledge") [45]. The book was translated into German and 
is currently considered a classical publication in medical philosophy [46]. He also authored the paper "Co to jest choroba" (1905) ("What is the nature of disease?") [35].

Edmund Faustinus Biernacki died in Lvov and was buried at Łyczakowski Cemetery. In 2015, Professors Zbigniew Dąbrowski and Aleksander Skotnicki initiated collecting funds for renovation of the run-down tomb of Biernacki. The tomb was located. The Polish Society of Rheumatology contributed to the funds. Thanks to the activity of the above-mentioned professors, the Polish Post issued a stamp commemorating Edmund F. Biernacki.

The ESR is a well-known laboratory test, widely applied in clinical practice [47-49]. Despite its application for decades, there is a lack of cognizance of the Polish inventor of the test, and rheumatologists should contribute to the promulgation of the history of the ESR and the role of its discoverer, Edmund Faustinus Biernacki.

The author declares no conflict of interest.

\section{References}

1. Judkiewicz L, Kasznicki M. Opadanie krwinek czerwonych przydatność kliniczna (90 lat odczynu Biernackiego). Pol Tyg Lek 1988; 43: 1102-1104.

2. Dąbrowski Z, Skotnicki A. Historia odkrycia znaczenia szybkości opadania erytrocytów (OB) w patologii człowieka (w 150 rocznicę urodzin polskiego lekarza i naukowca Edmunda Biernackiego). Przegl Lek 2016, 73: 343-348.

3. Kucharz EJ. Dr. Edmund F. Biernacki: life and contribution to the discovery of erythrocyte sedimentation rate. Acta Med Hist Rigen 1997; 3: 47-54.

4. Madraneas J, Potter P, Cairns E. Giving credit where credit is due: John Hunter and the discovery of erythrocyte sedimentation rate. Lancet 2005; 366: 2140-2141.

5. Biernacki E. O stosunku osocza do ciałek czerwonych i o wartości różnych metod oznaczania ogólnej objętości krążków. Pam Tow Lek Warsz 1894; 90: 32-72.

6. Biernacki E. Samoistna sedymentacya krwi, jako naukowa i praktyczno-kliniczna metoda badania. Gaz Lek 1897; 17: 962 968, 996-1004.

7. Biernacki E. Samoistna sedymentacya krwi, jako kliniczna i biologiczna metoda badania. Pam Tow Lek Warsz 1897; 43 823-824.

8. Biernacki E. Blütkörperchen und Plasma in ihren geenseitingen Beziehungen. Wien Klin Wsch 1894; 44: 1558-1580, 1599 1602.

9. Biernacki E. Über die beziehung des plasmas zu rothen Blütkörperchen und den Werth verschiendener Methoden den Blütkörperchen-volumenbestimmung. Zschr Physiol Chem 1894; 9: 179-224.

10. Biernacki E. Die spontane Blutsedimentirung als eine wissenschaftliche und praktisch-klinische Untersuchungsmethode. Dtsch Med Wschr 1897; 48: 769-772.
11. Fåhræus R. Über die ursachen der verminderten suspensionstabilität der Blütkörperchen während der Schwangerschaft. Biochem Z 1918; 89: 355-364.

12. Fåhræus R. The suspension-stability of the blood. Acta Med Scand 1921; 55: 1-128.

13. Westergren R. Studies on suspension stability of the blood in pulmonary tuberculosis. Acta Med Scand 1921; 54: 247-282.

14. Westergren R. Die Senkungsreacktion, algemaine-klinische Ergebnisse praktische bedeutung bei Tuberkulose. Springer Verlag, Berlin 1924.

15. Hirschfeld L. Über ein neues Blutsymptom bei Malariakrankheit. Correspondez-Blatt für Schwaitzer Arzte 1917; 47: 10071012.

16. Kucharz EJ. Towarzystwo Internistów Polskich. In: Słownik polskich towarzystw naukowych, Sordylowa B. (ed.). Vol. I. Polska Akademia Nauk, Warszawa 2004; 773-779.

17. Kucharz EJ. 80th Anniversary of the discovery of erythrocyte sedimentation rate. Mat Med Pol 1975; 7: 344-346.

18. Kucharz EJ. 80e anniversaire de la decouverte du test de la vitesse de sedimentation sanguine. Mat Med Pol (ed. franc.) 1975; 7: 344-346.

19. Kucharz EJ. Edmund Biernacki and the erythrocyte sedimentation rate. Lancet 1987; 1 (8534): 696.

20. Kucharz EJ. The forgotten contribution of Dr. Edmund Faustyn Biernacki (1866-1911) to the discovery of the erythrocyte sedimentation rate. J Lab Clin Med 1988; 112: 279-280.

21. Grzybowski A. Who discovered the erythrocyte sedimentation rate? J Rheumatol 2011; 38: 1521-1522.

22. Mattenson EL, Rahman MU, Crowson FL. A reply. J Rheumatol 2010; 97: 2.

23. Crowson CS, Rahman MU, Matteson EL. Which measure of inflammation to use? J Rheumatol 2009; 36: 1606-1610.

24. Rytel A. The sixtieth anniversary of development of the sedimentation test by Edmund Biernacki. Pol Med Hist Sci Bull 1957; 1: 3-7.

25. Uniśkiewicz B. Sources of controversy in blood sedimentation tests. Perspectives of the Edmund Biernacki's method. Organon 2002; 31: 149-164.

26. Kowalczyk J. Professor Edmund Biernacki (1866-1911). S Afr Med J 2006; 96: 40-41.

27. Olshaker JS, Jerrard DA. The erythrocyte sedimentation rate. J Emerg Med 1997; 15: 869-874.

28. Smoluchowski A. Edmund Biernacki jako odkrywca metody opadania krwinek, czyli tzw. odczynu Biernackiego. Przegl Lek 1947; 3: 656-6584, 696-700; 811-815, 852-856.

29. Kucharz EJ. Sto pięćdziesiąta rocznica urodzin Edmunda Faustyna Biernackiego - twórcy testu pomiaru szybkości opadania krwinek czerwonych. Forum Reumatol 2016; 2: 194-198.

30. Kucharz EJ. Dr. Edmund Faustyn Biernacki i jego odkrycie (w stulecie odkrycia odczynu opadania krwinek czerwonych). Pol Arch Med Wewn 1994; 92: 442-447.

31. Biernacki E. Wpływ na krew i wydzielanie moczu roztworów solnych, wprowadzonych pod skórę w wielkiej ilości. Pam Tow Lek Warsz 1888; 84: 594-610.

32. Kucharz EJ. Lancet i pióro. Zarys dziejów prasy studentów medycyny i farmacji w Polsce. In: Studencka praca medyczna, Doroba A (ed.). Wydawnictwo „Nowego Medyka”, Warszawa 1980; $13-87$. 
33. Guzek JW. Edmund Biernacki. Acta Physiol Pol 1987; 38: 170-176.

34. Grzybowski A, Sak J. Edmund Biernacki (1866-1911): discovery of the erythrocyte sedimentation rate. On the 100th anniversary of his death. Clin Dermatol 2011, 29: 697-703.

35. Grzybowski A, Sak J. Setna rocznica śmierci Edmunda Biernackiego - filozofa medycyny i wynalazcy metody pomiaru szybkości sedymentacji erytrocytów. Arch Hist Filoz Med 2011; 74: 29-36.

36. Szumowski W. Biernacki Edmund Faustyn. In: Polski Słownik Biograficzny, Warszawa 1937, t. 2: 78-79.

37. Ebel S. Professor Dr. Edmund Biernacki. Münch Med Wschr 1912; 59: 313-314.

38. Biernacki E. Po sezonie w Karlsbadzie. Medycyna 1904; 32: 987-900, 1007-1009, 1022-1024.

39. Biernacki E. Zarys patologii krwi. Druk K. Kowalewskiego, Warszawa 1905.

40. Biernacki E. Analgezya nerwu łokciowego, jako objaw wiądu rdzenia. Gaz Lek 1894; 29: 35-39.
41. Paciorkiewicz M. W 80 rocznicę opisania odczynu Biernackiego. Pol Tyg Lek 1979; 34: 1365-1366.

42. Smoluchowski A. Odczyn Biernackiego i jego odkrycie. Zdr Publ 1949; 65: 89-95.

43. Zawadzki J. Śp. Edmund Biernacki. Med Kronik Lek 1912; 47: 24-27.

44. Pruszyński J. Śp. Edmund Biernacki. Gaz Lek 1912; 32: 37-42.

45. Biernacki E. Istota i granice wiedzy lekarskiej. Drukarnia Granowskiego i Sikorskiego, Warszawa 1899.

46. Biernacki E. Die moderne Heilwissenschaft, Wesen und Grenzen des ärztlischen Wiessens. Verlag BG Teubner, Leipzig 1901.

47. Lisowski W. Profesor dr Edmund Biernacki - odkrywca nowych metod diagnostycznych. Lek Wojsk 1980; 56: 401-406.

48. Cienciała T. Edmund Biernacki - wybitny patolog i twórca metody określania szybkości opadania krwinek. Wiad Lek 1965; 28: 1825-1828.

49. Uniśkiewicz B. Odczyn Biernackiego i jego losy w ciągu stulecia. Pol Tyg Lek 1992; 47: 980-982. 